\title{
Graduate's Perception towards Entrepreneurial Career Choice: Role of University and Family
}

\author{
Umar Abdullahi Ahmed ${ }^{1}$, Most. Asikha Aktar ${ }^{2}$,Abu Sufian Abu Bakar ${ }^{3}$ \\ ${ }^{1}$ Kaduna State University, Kaduna-Nigeria. \\ ${ }^{2}$ Comilla University, Cumilla, Bangladesh \\ ${ }^{3}$ Universiti Utara Malaysia, Malaysia \\ umed313@yahoo.com \\ asikharita@gmail.com \\ sufian@uum.edu.my
}

\begin{tabular}{ll}
\hline ARTICLE DETAILS \\
\hline History & \\
Received $\quad$ February \\
Revised Format $:$ March \\
Accepted : April \\
\end{tabular}

Keywords :

career choice; student's perceptions; role of university; role of family; entrepreneurship

\begin{abstract}
S
In today's dynamic world, entrepreneurship is gaining greater attention both by the policymakers and scholars because of growing unemployment problems across the globe. Entrepreneurs remain vital as they contribute to crack-down on the rising societal challenges through the generation of new employment opportunities. Despite the growing acceptance of entrepreneurship in today's dynamic \& competitive environment, some graduates are not comfortable pursuing their career as entrepreneurs. What perceptions they carry regarding entrepreneurship as their career choice and who can nurture their positive entrepreneurial perceptions are crucial matters, thus encouraging researchers to conduct in-depth study along this line. By considering this issue, the present study sought to know the perceptions of university graduates regarding entrepreneurship career and who influences their perceptions. Based on the above reasons, this study was conducted in two universities in Malaysia: Universiti Utara Malaysia (UUM) and Universiti Malaysia Kelantan (UMK) and taken entrepreneurial perceptions as a function of the role of university and family. The study results reveal that 57 percent of the students want to start their career as entrepreneurs after graduation. Still, several factors can make barriers for them to enter into the business environment. In this context, the majority of students mentioned insufficiency of funds as the most significant obstacle, while the desire to get rich forces them to take such a hindrance as a challenge and the key to success in an entrepreneurial career. Though the study also identifies that both university and the family play positive roles in influencing student's entrepreneurial perceptions, the family contributes more than the university. Hence, this study hopes to contribute to the entrepreneurship literature by enhancing the understanding of the entrepreneurial perception of university graduates and also provides some basis for future research in this area. As the majority of students' perception is directly inclined towards selecting entrepreneurship opportunities as a career, the findings from the current study would also assist governmental institutions, affected agencies, academic institutions, entrepreneurial mentors, dedicated consultants, as well as counsellors to enhance students' perceived feasibility of self-employment by providing them relevant startup opportunities.
\end{abstract}

\section{INTRODUCTION}

The rising rate of unemployment especially youth unemployment remains one of the disturbing socio-economic problems especially within developing and underdeveloped

*Corresponding Author Email Address: umed313@yahoo.com (C) 2021 STIM Lasharan Jaya Makassar 
countries (Harmse et al. 2009). Hence in recent past, researches of the entrepreneurshipunemployment relationship have drawn significant attention among academics, government officials and policymakers within national, regional and international levels (Eam et al., 2020; Sahban, 2016). The rising prominence of entrepreneurship as a cardinal vehicle towards economic growth stimulation alongside employment generation for a large number of graduates is gaining wide recognition among researchers and policymakers (Jones et al. 2017; AbisugaOyekunle et al. 2020; Stamboulis \& Barlas, 2014). Hence, to proffer effective ways of tackling graduates unemployment crisis, 'self-employment' or 'entrepreneurship' is put forward as one of the effective channels (Koe, 2016; Sandhu et al. 2011).

This, among others, can be related to the urgent need for sustainable growth coupled with the challenges associated with rising unemployment issues globally. Recently, several academic works from prominent journals in this area, such as the Harvard Business Review, M.I.T. Sloan Management Review, as well as Journal of Business Venturing, among others, have suggested that entrepreneurial ideas can proffer solutions to numerous economic, environmental and social challenges (see Hall et al., 2010; Senge et al., 2007; Wheeler et al., 2005). Furthermore, other brochures from reputable international organisations such as the UE Strategy (2020), have also identified entrepreneurship waves and sustainability as a credible guarantee towards future development in various societies.

Hence, in the recent past, there has been rising interest in undertaking and strengthening engagements to stimulate and support such notion of entrepreneurship which remains an attractive substitute to wage occupation, especially among graduates globally. Ronstadt (1990) has concluded that the presence of graduate entrepreneurs could further enhance a country's competitiveness. Even as salary employees, graduates entrepreneurs can contribute more to an organisation. The importance of entrepreneurship as a cardinal means of job creation cannot be over-emphasised especially within the rising crisis of graduate unemployment (Cheratian et al. 2019). Several studies have been carried out to device ways of tackling global graduates' unemployment problems and the potential roles of entrepreneurship (see Drucker, 1985; Matos \& Hall, 2007; Schumpeter, 1934, 1942).

With this, encouraging graduates to embrace entrepreneurship and also consider it as an essential avenue for career selection in many developing economies, including Malaysia is also increasing (Ambad \& Damit, 2016). Entrepreneurship has been regarded as one of the solutions to graduate-related unemployment in Malaysia. Indeed, entrepreneurship by graduates is one of the emphases in the Malaysian government policy agenda within in its quest to be a highly developed nation by 2020. Currently recognises the importance of graduate entrepreneur as an action to unemployment problems, the Government of Malaysia has continued to articulate and encourage the spirit of entrepreneurship among graduates regardless of their specialisation. For example, a Critical Agenda Project (CAP) has been established for graduate entrepreneur development. Various entrepreneurship programs, training and workshops are implemented in higher education institutes. Moreover, a one-stop Centre to empower entrepreneurs has been established. Despite the extensive efforts in cultivating graduate entrepreneurs, the number of graduates who become an entrepreneur is not encouraging.

In 2010 for example, there were only around 5\% of university graduates becoming entrepreneurs (Ministry of Higher Education, 2011). In terms of the intention to be entrepreneurs, According to the report of Global Entrepreneur Monitor (2015), among Malaysians who were in aged of 18-64 years, about half of them agreed that entrepreneurship remains a right career choice. This percentage was relatively low compared to other countries. Moreover, there were only about $10 \%$ of them (who agreed that entrepreneurship remains a right career choice) who intended to be entrepreneurs.

Previous studies have found many generalisable explanations regarding the issue. Khursheed (2017) clarified that growing up in an entrepreneurial family unit significantly affects the perception of a person towards entrepreneurship. Other research studies have examined and argued that family factors are an essential explanation to influence individual perception to become an entrepreneur (Nicolaou et al., 2008; Nicolaou \& Shane, 2009; Sahban et al., 2016). 
On the other hand, there is a significant role played by the university which has been celebrated as being able to raise the level of consciousness and encourage self-employment as an alternative career especially among the youth ( see Clayton 1989; Fleming 1996). Furthermore, universities can serve as possible cradles of imminent entrepreneurs, because the educational support provided by such institutions often affects the student's perception in the selection of their job (Garavan \& O'Cinneide, 1994).

However, what remains unclear so far, is what perception do graduates have to choose an entrepreneurial career, and who shapes their perceptions to be an entrepreneur is a crucial matter of fact in the context of Malaysia, therefore, encouraged researchers to conduct such a study. Based on this unrestrained backdrop, it remains critical to have a clearer understanding of potential graduates perception on the context of embracing it as a career choice and the roles such factors like university and the family play in influencing such decisions of career choice. This study contributes to the area of entrepreneurship, especially with regards to the roles of university and the family. Furthermore, it will enable governments at all levels, institutions within private or public domain, other agencies, academia, entrepreneurial instructors, and consultants to understand the perception of graduates about entrepreneur career, and how much their educational institution and family influence their perceptions.

\section{LITERATURE REVIEW}

There seems to be no formal definition that can be assigned to entrepreneurship as a result of inadequate consensus regarding that (Zhao, 2005). In this regard, Kim (2008) maintains that defining the term entrepreneurship as well as the entrepreneur remains a challenging and tenacious duty. Nonetheless, numerous definitions have been acknowledged and regarded as appropriate in describing entrepreneurship within the available literature, and such can also be relevant to this study. However, another strand of literature sees entrepreneurship on the viewpoint of strategic management perception. On this note, for instance, Miller (1983) describes entrepreneurship as any activity within the organisational scope that focuses on creative efforts, risk-taking endeavours and reactiveness. Similarly, earlier efforts of defining entrepreneurship focus aspects of the perception of entrepreneurs to undertake planned business-related abilities and risks (Brockhaus, 1980). It then entails that the absence of perception include willingness (Davidson, 1991 to undertake risk-related ventures can serve as a significant barrier to entrepreneurial activity.

Conceptually, entrepreneur perception can be explained by using the "social cognitive career theory" (SCCT) which is established based on the overall "social cognitive theory" of Bandura (1986) (Lent et al., 1994, 2000) is a vocational psychology theory. The theory elucidates that perception, through the senses, is a procedure of becoming conscious of the environment the person lives in. Consequently, how an individual perceives the universe will define how responding to it will be. In trying to assign a more exact meaning, perception requires analysing and interpreting objects selected by the senses. Hence, analysing and interpreting a sensory acceptance is influenced by various causes including both human (endogenous) and environmental/contextual elements (exogenous such as discrepancies in socialisation patterns, routine opportunities, formation and modelling, as well as social inspirations) (Lent \& Brown, 2019).

The perception of prospect, as well as motivation, access to available means to followup the prospects, can be seen as a prerequisite situation to entrepreneurial behaviours. Hence, having an optimistic perception of entrepreneurship may likely encourage an individual to go into the act of entrepreneurship (GEM, 2010). Studies in areas of graduates' perception of entrepreneurship have shown that family and university have a maximum effect on how graduates recognise entrepreneurship as a possible career choice (M. Sahban et al., 2016). Moreover, Altinay et al. (2012) identified the influence of socio-demographical variables where, in particular, the role of the family background has an impact on forecasting entrepreneurial intentions among students in the UK. The study further concludes that family 
upbringing and backing has a positive influence on the results in entrepreneurial undertakings. On the same pattern, Searman et al. (2016) maintain that despite the vital roles many factors play in determining intention and development towards entrepreneurship and business continuation, the family still serves an excellent guide and influence.

On their part, Edelman et al. (2016) maintain that the family plays instrumental support from two angles of the financial ground and social capital towards entrepreneurial intension. While, the family as a component of social capital has positively influenced the possibility of entrepreneurial choice towards start-up undertakings, and the financial capital component of the family has a negative influence with start-up undertakings. The role of the family in influencing individual's activities has been established in various ways. In this pattern, for example, it impacts on the nature of self-confidence, creative ability, attitude, conduct, and tendencies towards risk-taking; family alongside parents and guardians have considerable influence on the career selection and choice making (Szinovacz, 1996; Lotfizadeh \& Hanzaee, 2014; Stamboulis \& Barlas, 2014; Rahmawati et al., 2012).

Hence, with the recognition of the vital roles of the family for being supportive of the whole path and process of entrepreneurial undertakings, the idea generation stage, however, remains the most significant aspect in the process which on several cases is done by the family (Edelman et al. 2016). Furthermore, such considerable influence from the family can be taking to be immensely influential on intention and perception as well (Ahmed et al., 2020). As the parents-the father and the mother-of any potential entrepreneur remain essential role models, influencing such individual's intention and perception is also noteworthy by the parents (Moreno-Gomez et al. 2019). On a related ground, Pham et al. (2019) further assert that parents, for example, the father play various roles in numerous learning and developmental levels. In such a situation, for example, serving as an exemplary role model during the young age of a child, a reliable supporter during educational pursuits and mentor as well as distress-shooter at any period of venture conception, establishment and managerial requirements. On this regard, the role occupied by the family cannot be under-estimated in the process of entrepreneurship.

Peterman and Kennedy, (2003) and Souitaris et al., (2007) investigated the roles of universities as institutions that provide and enable a favourable environment for supporting entrepreneurial perception and intention that can lead to the creation of new ventures. Generally speaking, entrepreneurship education and in particular university system have significantly played some vital roles in influencing entrepreneurial intention and perception, especially among students (Turker \& Selcuk, 2009; Garavan and O'Cinneide, 1994). Hence, researches have shown that university alumnae are playing significant roles in establishing new businesses which enhance economic multiplier outcomes in the form of income generation and creation of employment opportunities (Carree \& Thurik, 2005; Richert \& Schiller, 1994). The rising societal needs from one angle and the increasing ambitions of students as prospective entrepreneurs on the other direction, universities worldwide are providing courses related to entrepreneurship, thus influencing the perception of students (Postigo, 2002). Such instances can also offer a healthy guide, support and necessary assistance to capable students. On this basis, therefore, expectations are high that universities will play crucial roles in various economies to foster entrepreneurship and inspire students to embrace it as a viable alternative career.

The review of earlier literature shows there exist a clear connection between the two elements, which are family and university, with the perception of graduates to be an entrepreneur. Such a relationship happens based on the review of available literature as guided by the "social cognitive career theory" (SCCT), the following research model is developed for the current study as presented in Figure 1 below. 


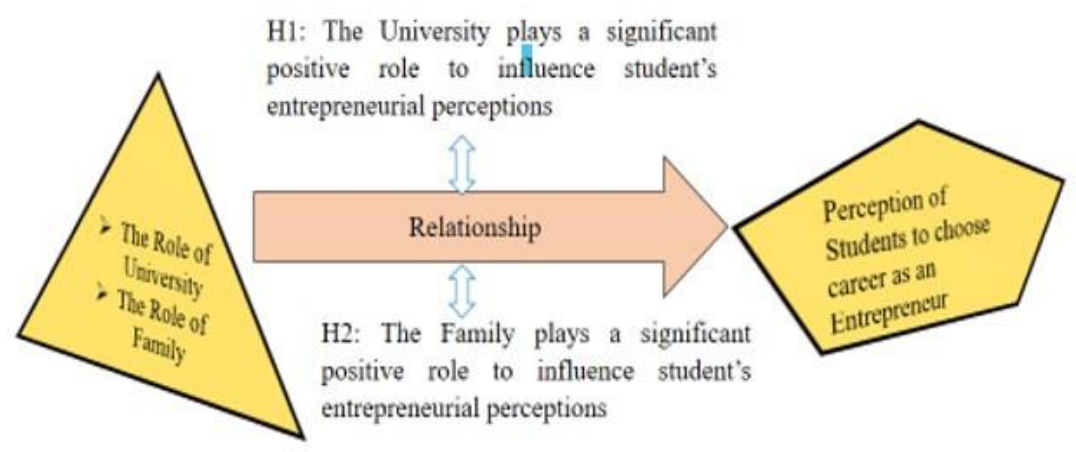

Figure 1: Research Framework

Entrepreneurship remains an essential result of individual efforts and expressions, alongside certain environmental and societal situations, such as family influences and educational institutional roles also serve as crucial factors that stimulate venturing into entrepreneurship and its propensity (Chang et al., 2019). Bearing such a premise in mind, the present study recognises the vital role of all factors within endogenous and exogenous nature. However, the exogenous factors which are in the form of family support and influence, as well as university roles, are of equal importance in determining the outcomes associated with entrepreneurship perception.

\section{RESEARCH METHODOLOGY}

\section{Methodology}

Using a sample size of 489 graduates from Universiti Utara Malaysia (UUM) and Universiti Malaysia Kelantan (UMK), this study examines the effect of the graduate's career choice toward entrepreneurship. To examine the hypotheses, data collection was conducted via a "self-administered questionnaire". Furthermore, the questionnaire utilised the close-ended questions through a five-point Likert scale. The Statistical Package for Social Sciences (SPSS) version 22.0 was employed for the data analysis. Descriptive analysis was performed to present the perception of graduates to be an entrepreneur while a single regression was used to examine the hypothesised propositions. For the current study also, a reliability coefficient of 0.50 is set as the criterion of acceptability (Helmstater 1964; Felder and Spurlin 2005). For factor analysis, as a rule of thumb, a factor with higher loadings (greater than 0.3) is chosen to represent a factor due to its more significant influence and more important (Hair, Anderson et al. 1998). Graduates' perception was measured with five questions (Cronbach's alpha is 0.997). The role of the university was measured with seven questions (Cronbach's alpha is 0.845) and the role of family members measured with three questions (Cronbach's alpha is 0.990) (Sahban et al., 2015). Therefore the values of Cronbach's alpha indicates that all of the selected items in the questionnaire put up with high and consistent reliability values. Refer to Appendix A for all items utilised in this study.

\section{RESULTS AND DISCUSSIONS}

\section{Graduates perception to choose an entrepreneurial career}

\section{$\underline{\text { Respondents Demographic Profile }}$}

With the influence of people's inter-relations with the rest of the world in shaping individuals' perceptions, this study presents demographic features below in order provide the likely environmental elements to of respondents in a bid to define how such factors and their possible effects on the respondents' perception about entrepreneurship. 


\begin{tabular}{cccc}
\hline \multicolumn{2}{c}{ Characteristics } & Frequency & Percent \\
\hline \multirow{2}{*}{ Sex } & Male & 246 & 50.3 \\
\cline { 2 - 4 } & Female & 243 & 49.7 \\
\hline Marital status & Single & 456 & 93.3 \\
\cline { 2 - 4 } & Married & 33 & 6.7 \\
\hline Religion & Muslim & 390 & 79.8 \\
\cline { 2 - 4 } & Christian & 20 & 4.1 \\
\cline { 2 - 4 } & Buddha & 55 & 11.2 \\
\hline \multirow{2}{*}{$\begin{array}{c}\text { Pntreprents } \\
\text { history }\end{array}$} & Others & 23 & 2.7 \\
\cline { 2 - 4 } & Father is an entrepreneur & 112 & 18.4 \\
\cline { 2 - 4 } & Mother is an & 90 &
\end{tabular}

Source: Research data

Out of 489 usable questionnaires, the male respondents were slightly higher, with 50.3 percent compared to female respondents with 49.7 percent. In terms of marital status, majority were single with 93.3 percent. When it comes to the respondents' religious status, 79.8 percent are Muslims, 4.1 percent are Christians, while 11.2 percent are Buddha and others 4.7 percent of the total respondents. Regarding the working history of the parents'; most of the fathers are currently or previously served as employed workers (representing 77\%). On the other hand, the mothers were mostly unemployed or just house-wives (representing 82\%).

The graduates were requested to choose their level of agreement or otherwise based on a "five-point Likert scale" as to whether they are interested in entrepreneurship as a career option after graduation. To evaluate whether such graduates had entrepreneurship intentions, the scale was fused to only two point's dimension of agree or disagree. The table 2 below displays the percentage of graduates who are interested in pursuing entrepreneurial activities based on some specified demographic qualities.

Table 2: Graduates intension to entrepreneur

\begin{tabular}{cccc}
\hline & Characteristics & Agree (\%) & Disagree (\%) \\
\hline Sex & Male & 65 & 35 \\
Marital status & Female & 50 & 50 \\
Religion & Single & 57 & 43 \\
& Married & 73 & 27 \\
& Islam & 60 & 40 \\
Christian & Buddha & 30 & 70 \\
Parents & Others & 53 & 47 \\
Entrepreneurship & Father is an entrepreneur & 69 & 39 \\
history & & 62 & 31 \\
& Mother is an & & 38 \\
& entrepreneur & &
\end{tabular}

Source: Research data

Among 489 graduates, 281 graduates aforementioned that they want to start their first career as an entrepreneur after completion of their graduation. From the survey, it was shown that male graduates (65\%) express more interest than female graduates $(50 \%)$. Therefore most 
of the graduates show a strong desire to be an entrepreneur, especially who are married (70\%). High engagement of married persons implies that a married person has many responsibilities to maintain his family and always have a tendency to earn better income to gain social prestige as entrepreneurship among other informal sector jobs provides such chances. On the other hand, graduates who are coming from the Christian religion expressed a lower desire to pursue a career as entrepreneurs. The reason is that, although such Christians can choose any career most of them prefer working at churches or in para-church ministry rather than to work as an investor or businessman. Finally, graduates were asked whether their parents are entrepreneurs or not in order to evaluate whether a parental career in self-employment positively influenced their career or not. Parental entrepreneurship background is identified as a critical factor that guides the graduates' ambition toward a particular career path (Dalton \& Halloway, 1989; Scott \& Twomey, 1998; Harrison \& Hart, 1992;). Since parents can connect their children to the family business and after receiving continuous support from their family, the children engage themselves with their family business. Along the way, they become eager to choose it as their career sometimes without having any knowledge about it (Lentz \& Laband 1990). The findings indicate that among graduates whose father are entrepreneur, $69 \%$ of graduates would like to engage in entrepreneurship while, $62 \%$ of graduates whose mother are entrepreneur expressed their choice to entrepreneurship as a career.

\subsection{Graduates Perception to choose entrepreneur career}

The graduates were required to state their opinion based on "five-point Likert scale" at what level they agree with the statement confined in the questionnaire which characterises their perceptions to choose entrepreneur career as depicted in figure 2.

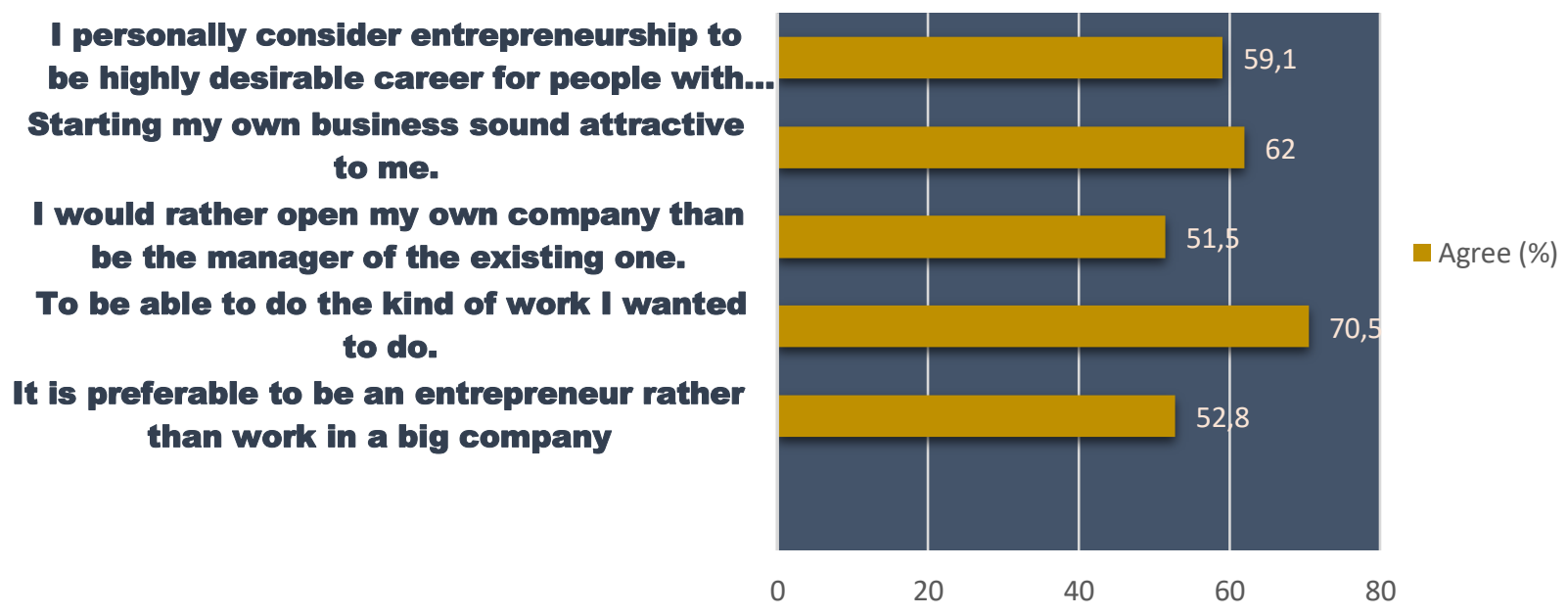

Figure 2: (\%) of student's perceptions to choose entrepreneur career Source: Research data

Figure 2 above illustrates that the respondents consider their own business as the most attractive career option in the future that people would like to do based on their ability. Almost 71 percent of respondents indicated that entrepreneurship provides such kind of opportunities that they want. However, about 62 percent graduates show positive perception to be entrepreneurs as they think that it is more pleasurable to start own business, while 59 percent personally perceived it as a highly desirable career option followed by rather than working as employed worker.

\section{Graduates perception of entrepreneurial motivational factors}

Table 3: Motivational factors to influence graduate perception, Mean values 


\begin{tabular}{c|c}
\hline Statement & Average mark \\
\hline The liberty of being one's own 'boss.' & 3.96 \\
\hline Lack of employment opportunity & 3.87 \\
\hline Opportunities to meet interesting people & 3.82 \\
\hline Influence of peer group, friends and family members & 3.60 \\
\hline The desire to get rich & 4.04 \\
\hline To gain social prestige & 3.72 \\
\hline Achieving an appropriate target in life by one's abilities & 3.98 \\
\hline
\end{tabular}

Source: Research data

According to table 3, there are seven motivational factors which have been considered by graduates as potential reasons for influencing their perception to choose entrepreneur career. The three essential motives are desire to get rich; liberty; and need for achieving a target. Respondents indicated that although there is a high risk to start-up business also have the chance to get rich more quickly compare to other occupations.

\section{Graduates perception of entrepreneurial characteristics}

The literature highlights various entrepreneurial characteristics of which selfmotivation, innovativeness and creativity, self-motivation, and aggressiveness are included (Holt, 2003; Hisrich, Peters and Shepherd, 2008). Graduates were asked whether they perceived these characteristics to be essential if they were to pursue a career in entrepreneurship. Figure 3 below, shows the perception of entrepreneurial features by graduates who had demonstrated that they desired to choose entrepreneur career.

\section{(\%)}

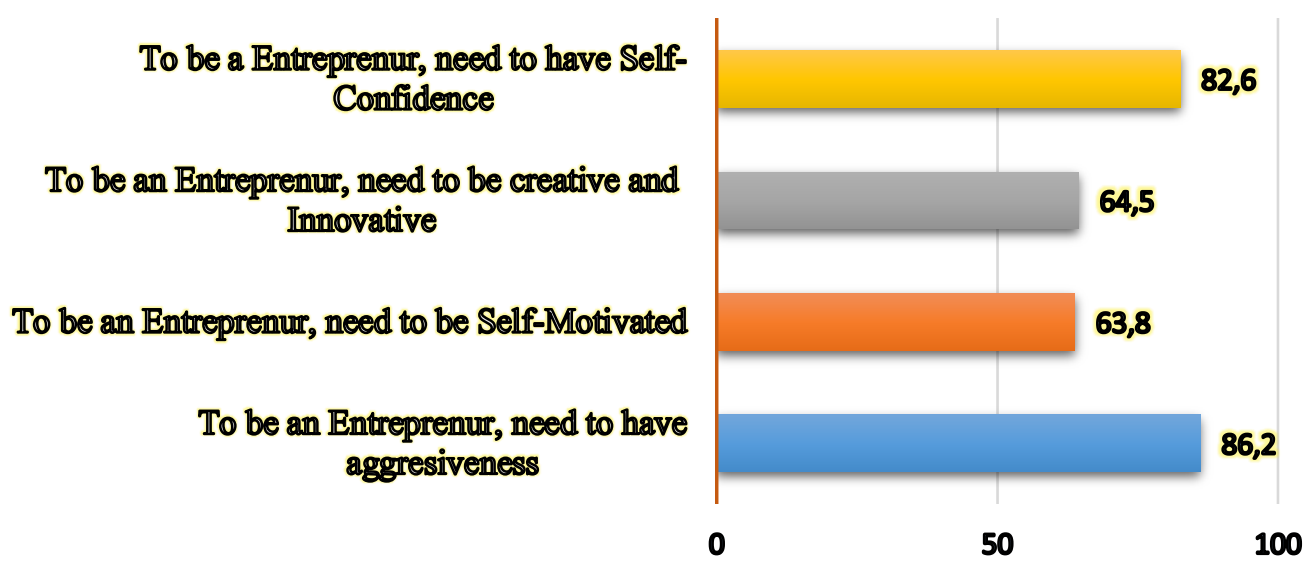

Figure 3: Perception of entrepreneurial characteristics by graduates

Source: Research data

Figure 3 presents that all the students who would want to choose entrepreneur career perceived aggressiveness as an essential feature of all the features listed. Their perception is that without a strong dedication, it is not possible to be a successful entrepreneur. Similarly, creativity and innovation alongside the level of self-confidence were also identified important by most of the students, but less perceived compare to aggressiveness and self-confidence where only 17 percent of graduates perceived self-confidence as less important. 
The challenges facing the business atmosphere concerning career opportunities may be seen as some of the barriers to entry. The many difficulties that graduates perceive towards a career within entrepreneurship circle may deter them from choosing such career as an entrepreneur if they identify the challenges as overwhelming. However, the same challenges can be seen as incentives for graduates, especially for those who are bold enough to overcome such challenges.

Hence to find out those likely challenges to graduates, they were also requested to respond on a "five-point Likert scale" to some factors about what could serve as a challenge in pursuing a career in entrepreneurship.

Table 4: Perception to challenges in entrepreneur career by graduates

\begin{tabular}{ll}
\hline Statement & Average Mark \\
\hline Insufficiency of funds & 4.04 \\
Lack of knowledge about business operations & 3.64 \\
Fear of failure/ strong competition/insecure income & 3.83 \\
Inability to bear mental pressure to run business & 3.81 \\
Bad experience of others in conducting business & 3.62 \\
Bureaucracy (i.e., difficulties to obtain licenses and certificates) & 3.66 \\
Local infrastructure (i.e., availability of business premises) & 3.52 \\
Adverse effect on social relationships & 3.30 \\
Entrepreneurship is excessively binding and time-consuming & 3.65 \\
General lack of appreciation of entrepreneurship & 3.46
\end{tabular}

Source: Research Data

The findings indicate that the inadequacy of funds has been perceived as the highest challenge by graduates. Their perception is that finance is identified as the key to business, and without having financial adequacy, no one can start a profitable business. Furthermore, there exists a lot of risks to run a business; this may include the fear to be failure, fear of being financial looser which may lead to mental stress. On the other hand, factors related to the society, such as the creation of an adverse effect on the relationships with the members of the society and lack of social appreciation of entrepreneurship career were perceived as less challenging.

\section{Role of university and family to influence graduates perception}

The relationships of factors with the interest of graduates to become an entrepreneur as the answer to the second research question as a purpose to fulfil the second objective of this study. The two factors consist of the role of the university (X1) and the role of family (X2) as independent variables, and the perception of graduates to become an entrepreneur ( $\mathrm{Y}$ ) as the dependent variable. Using the enter method, a significant model emerged as follows:

$$
\mathrm{Y}=\beta_{1}+\beta 2 \mathrm{X}
$$

The results of this study are as indicated in Table 5 below:

Table 5: Relationship between factors and perception of graduates to become an entrepreneur

\begin{tabular}{ccccc}
\hline $\begin{array}{c}\text { Independent } \\
\text { variable }\end{array}$ & $(\boldsymbol{\beta})$ & $\mathbf{t}$ & Sig. & Pedictor \\
\hline $\begin{array}{c}\text { The role of } \\
\text { university }\end{array}$ & 0.272 & 6.214 & 0.000 & $\mathrm{p}<0.05$ \\
\hline $\begin{array}{c}\text { The role of } \\
\text { family }\end{array}$ & 0.513 & 13.172 & 0.000 & $\mathrm{p}<0.05$ \\
\hline
\end{tabular}


The results from table 5 above indicate that university and family both have the highest significant relationship with the perception of graduates to choose entrepreneur career. The linear regression analysis shows that university role is the indicator with correlation $(\beta=0.272$, $\mathrm{t}=6.214$ and $\mathrm{p}=0.000)(\mathrm{p}<0.05)$. Thus, H1 will be accepted when the role of the university goes up by a unit; student's perceptions to choose entrepreneurship career will also increase to 0.297 unit. Similarly, the family plays a significant positive role influencing student's entrepreneurial perceptions with correlation $(\beta=0.513, \mathrm{t}=13.172$ and $\mathrm{p}=0.000)(\mathrm{p}<0.05)$. Thus, $\mathrm{H} 2$ will be accepted when the role of the family goes up by a unit; student's perceptions to choose entrepreneurship career will also increase up to 0.554 unit.

\section{CONCLUSION}

The Results of the study do not show that comprehensive income is superior to net income for firm performance evaluation, based on stock return. The same results prevailed at total sample and some industrial group level. Also, the result at total sample level do not show the superiority of comprehensive income to net income for firm performance evaluation, based on stock market price.

About "Other Comprehensive Income items" our results show that in state companies, adjusting net income for fixed assets revaluation and foreign currency adjustments, improves the ability of income to summarize firm performance. It is also appropriate for predicting operating net income.

In companies listed in Tehran Stock Exchange, except for investment industry group, we found no evidence that comprehensive income for firm performance evaluation on the basis of cash flows prediction to be superior to net income. We found better results for the state companies (only in other companies group), i.e., firm performance evaluation on the basis of cash flows prediction using comprehensive income, to be superior to net income.

Collectively, our results provide some weak evidence that show, comprehensive income adjustments improve ability of income for reflecting firm performance.

We propose further study of the issue in another research with the same methodology applied in this research, except that, first, the estimation of the best models that fit the data to be done, and second, using the best competing models to investigate the superiority of comprehensive income to net income.

\section{REFERENCES}

Abisuga-Oyekunle, O. A., Patra, S. K., \& Muchie, M. (2020). SMEs in sustainable development: Their role in poverty reduction and employment generation in sub-Saharan Africa. African Journal of Science, Technology, Innovation and Development, 12(4), 405419. https://doi.org/10.1080/20421338.2019.1656428

Ahmed, I., Islam, T., \& Usman, A. (2020). Predicting entrepreneurial intentions through selfefficacy, family support, and regret: A moderated mediation explanation. Journal of Entrepreneurship in Emerging Economies. https://doi.org/10.1108/JEEE-07-2019-0093

Ambad, S. N. A., \& Damit, D. H. D. A. (2016). Determinants of entrepreneurial intention among undergraduate students in Malaysia. Procedia Economics and Finance, 37(16), 108-114. https://doi.org/10.1016/s2212-5671(16)30100-9

Cheratian, I., Golpe, A., Goltabar, S., \& Iglesias, J. (2019). The unemploymententrepreneurship nexus: new evidence from 30 Iranian provinces. International Journal of Emerging Markets, 15(3), 469-489. https://doi.org/10.1108/IJOEM-02-2019-0084

Harmse, A., Blaauw, P., \& Schenck, R. (2009). Day labourers, unemployment and socioeconomic development in South Africa. Urban Forum, 20(4), 363-377. https://doi.org/10.1007/s12132-009-9067-8 
Jones, P., Pickernell, D., Fisher, R., \& Netana, C. (2017). A tale of two universities : graduates perceived value of entrepreneurship education. Education+ Training, 59(7), 689-705. https://doi.org/10.1108/ET-06-2017-0079

Koe, W.-L. (2016). The relationship between Individual Entrepreneurial Orientation (IEO) and entrepreneurial intention. Journal of Global Entrepreneurship Research, 6(1). https://doi.org/10.1186/s40497-016-0057-8

Sahban, M. Amsal, Kumar, D., \& Ramalu, S. S. (2015). Instrument Development: Entrepreneurial Social Support Assessment Instrument (IESSA). Research Journal of Economic \& Business Studies, 4(3), 21-36.

Sahban, M., Ramalu, S. S., \& Syahputra, R. (2016). The Influence of Social Support on Entrepreneurial Inclination among Business Students in Indonesia. Proceedings of $5 \mathrm{Th}$ International Conference on Research Methods in Management \& Social Sciences (ICRMMS-2016).

https://www.researchgate.net/profile/Aprizal/publication/332413285_International_Foun dation_for_Research_and_Development_IFRD/links/5cb40dada6fdcc1d4995a108/Intern ational-Foundation-for-Research-and-Development-IFRD.pdf\#page $=58$

Sahban, Muh Amsal. (2016). Determinants of Entrepreneurial Intention among Business Students in Indonesia. Universiti Utara Malaysia.

Sandhu, M. S., Sidique, S. F., \& Riaz, S. (2011). Entrepreneurship barriers and entrepreneurial inclination among Malaysian postgraduate students. International Journal of Entrepreneurial Behaviour \& Research, 17(4), 428-449. https://doi.org/10.1108/13552551111139656

Stamboulis, Y., \& Barlas, A. (2014). Entrepreneurship education impact on student attitudes. International Journal of Management Education, 12(3), 365-373. https://doi.org/10.1016/j.ijme.2014.07.001

Zhao, F. (2005). Exploring the synergy between entrepreneurship and innovation. International Journal of Entrepreneurial Behaviour and Research, 11(1), 25-41. https://doi.org/10.1108/13552550510580825 